\title{
W odpowiedzi Tomaszowi Siewierskiemu
}

$\mathrm{Z}$ zainteresowaniem przeczytałem utrzymane $\mathrm{w}$ emocjonalnym tonie uwagi Tomasza Siewierskiego, dotyczące mojego tekstu o historykach wojskowości, uczniach Stanisława Herbsta ${ }^{1}$, które ukazały się w numerze 1/2020 „Przeglądu Historyczno-Wojskowego"2. Nie spodziewałem się, że mój adwersarz również zajmuje się tą tematyką a znamy się wiele lat. Wobec licznych zarzutów postanowiłem się do nich odnieść.

Moja publikacja nie rościła sobie prawa do wyczerpania tematu. W takim wypadku niezbędna byłaby osobna monografia, nad którą - jak wiem - pracuje prof. Jerzy Maroń. W przypadku przedstawienia uczniów Herbsta postąpiłem podobnie, jak $\mathrm{w}$ dwóch innych moich artykułach ${ }^{3}$. Opisałem 41 postaci na 40 stronach, więc trudno rościć pretensje, aby praca była wyczerpująca. Uwagi Siewierskiego są w dużej mierze chybione, gdyż mają jedynie charakter uzupełniający. Przy tak dużej liczbie faktów było możliwe popełnienie błędów. Faktycznie praca doktorska Józefa Chęcińskiego nie została obroniona - na co zwrócił mi uwagę już prof. Jerzy Maroń. Co do innych uwag Recenzenta, są one, niestety, w dużej mierze nieprawdziwe.

Autor polemiki zarzucił mi nieprzeprowadzenie kwerendy w Archiwum Uniwersytetu Warszawskiego (UW). Faktycznie, ze względu na objętość i czas powstania tekstu nie było to możliwe. Przeprowadzanie z kolei badań w Archiwum Politechniki Warszawskiej oczywiście byłoby potrzebne, gdybym pisał książkę o wszystkich uczniach Stanisława Herbsta. Jednak celowo ograniczyłem artykuł do wskazania jedynie tych uczniów warszawskiego historyka, którzy zajmowali się historią wojskowości. Nie jest prawdą, jakoby moja kwerenda ograniczyła się tylko do zespołu dawnej Wojskowej

${ }^{1}$ M. Kozłowski, Historycy wojskowości - uczniowie Stanisława Herbsta, „Przegląd Historyczno-Wojskowy" (PHW) 2019, nr 4 (270), s. 108-155.

${ }^{2}$ T. Siewierski, Jak nie uprawiać historii historiografii: uwagi na marginesie artykułu Michała Kozłowskiego, PHW 2020, nr 1 (271), s. 241-250.

${ }^{3}$ M. Kozłowski, Oskar Halecki i jego uczniowie. Wzajemne relacje po latach [w:] Oskar Halecki i jego wizja Europy, t. 3, red. M. Dąbrowska, Warszawa-Łódź 2014, s. 24-77; idem, Nauczyciel i wychowawca. O uczniach Stanisława Kościałkowskiego [w:] Stanisław Kościatkowski pamięci przywrócony, red. M. Dąbrowska, Warszawa-Łódź 2016, s. 130-179. 
Akademii Politycznej. Autor sam sobie zaprzecza, pisząc dalej, że zaniechałem tam kwerendy. W jaki sposób może ocenić, czy przeprowadziłem tam kwerendę, czy nie? Nie odniosłem wrażenia, że Tomasz Siewierski jest znawcą tego archiwum i bywa w nim często - co pozwalałoby mu się stawiać na pozycji znawcy i autorytetu. Wbrew pozorom nabycie wiedzy o zawartości archiwum na odległość jest mało możliwe. Wskazane dokładnie przypisy źródłowe przeczą temu, co napisał.

Uwzględniłem także materiały z Instytutu Pamięci Narodowej, czego autor zupełnie nie zauważył. Nie mogę też zrozumieć reakcji na wykorzystanie listy doktoratów obronionych na Wydziale Historycznym UW. Wszedłem w jej posiadanie dzięki uprzejmości dr. Siewierskiego i skorzystałem z jego rady, by się oprzeć na niej w pracy naukowej nad tematem.

Autor zupełnie nie rozumie relacji mistrz - uczeń, zarzucając mi nieuwzględnienie kilku osób. Nie traktuje się takiej relacji tylko jako formalnego zrobienia pod czyimś kierunkiem magisterium lub doktoratu. Idąc tym tokiem rozumowania, Bogdan Borusewicz jest uczniem Ryszarda Bendera, a Donald Tusk z kolei Romana Wapińskiego. Mam pewne wątpliwości, czy promotor doktoratu Tomasza Siewierskiego, prof. Mirosław Filipowicz, uznałby się za ucznia Czesława Blocha - swojego z kolei promotora. Stąd też uwagi o Barszczu i Jaworskim są zupełnie nietrafione.

Przyznaję, że popełniłem błąd w przypadku Chęcińskiego, który nie obronił rozprawy doktorskiej. Jednak nie jest prawdą, że nie cytuję pracy Ireneusza Pielesiaka, gdyż robię to kilkakrotnie w tekście (s. 138, przyp. 91; s. 145, przyp. 116). Trudno bym zgodził się także z opinią na temat historiografii partyjnej. Mam prawo do innego zdania. Jaki związek z oceną naukową ma to, iż Andrzej Janowski był członkiem Armii Krajowej i miał pewien - a nawet znaczny - udział w początkowej idei stworzenia Muzeum Powstania Warszawskiego? Moim zdaniem nie kłóci się to z tym, iż można go zaliczyć do grona historyków partyjnych. Nie jest też istotne - jak twierdzi Siewierski - że prace o Stronnictwie Narodowym było trudno wówczas wydać bądź było to niemożliwe. Problemem jest raczej sposób, w jaki pisano wtedy o Stronnictwie Narodowym.

Zaskoczenie budzi opinia Autora o prof. Czesławie Blochu, jakoby jego pobyt na Syberii zdeterminował całe jego życie. To psychologizacja oparta na przeczuciach metafizycznych, ale nie mająca wiele wspólnego $\mathrm{z}$ analizą historyczną - to raczej wrażenie literackie. Nie bardzo rozumiem dlaczego sugestia, że był podporucznikiem Korpusu Bezpieczeństwa Wewnętrznego (KBW), ma charakter insynuacyjny. Zapewne Siewierski tego nie wie, ale późniejszy historyk z Katolickiego Uniwersytetu Lubelskiego zgłosił się na ochotnika do tej formacji w 1947 roku . Ukończył także w 1949 r. szkołę

\footnotetext{
${ }^{4}$ Archiwum Instytutu Pamięci Narodowej w Lublinie, Akta personalne Czesława Blocha, $289 / 464$.
} 
oficerską KBW w Legnicy. Dodatkowo warto dodać informację, że jego brat był pracownikiem referatu łączności Komitetu Centralnego Polskiej Zjednoczonej Partii Robotniczej. Informacje o współpracy z bezpieką podałem zresztą za pracą Macieja Sobieraja, o czym Siewierski nie informuje, świadomie wprowadzając czytelnika w błąd.

Uwagi Tomasza Siewierskiego są w zasadzie realizacją znanej metody "kleju i nożyczek”, opisaną swego czasu przez brytyjskiego historyka Robina George’a Collingwooda. Metoda ta polega na umiejętnym wycinaniu fragmentów tekstu historycznego i umieszczaniu ich w dowolnej kolejności. $\mathrm{Z}$ dużego tekstu, który nie aspirował do wyczerpania tematu, wydobył jego pewne braki (któż ich nie ma), pasujące mu do z góry przyjętej tezy. Muszę też, niestety, zauważyć, że tekst nie jest wyłącznie odpowiedzią naukową. Mam wrażenie, że jego autora cechuje negatywny stosunek wobec mnie. Jego narracja jest nacechowana emocjami. Argumenty, interpretacja i wnioski zostały dobrane jednostronnie. Przy takim rozmiarze tematu błędy czy luki były nieuniknione. Warto jednak podkreślić, że praca przeszła pozytywnie proces recenzyjny wśród zorientowanych w temacie i zawartości archiwów wojskowych recenzentów „Przeglądu Historyczno-Wojskowego”.

Michał Kozłowski

(Wojskowe Biuro Historyczne im. gen. broni Kazimierza Sosnkowskiego) orcid.org/0000-0002-9372-9292 